\title{
Von Hippel-Lindau Disease Tumor Suppressor
}

National Cancer Institute

\section{Source}

National Cancer Institute. Von Hippel-Lindau Disease Tumor Suppressor. NCI Thesaurus. Code C17814.

Von Hippel-Lindau disease tumor suppressor (213 aa, $24 \mathrm{kDa}$ ) is encoded by the human VHL gene. This protein plays a role in protein ubiquitination and regulation of protein degradation. 